\title{
Effect of national chelated micronutrient fertilizers on the productivity of grape plants and quality indicators of wine
}

\author{
Natalia Aleynikova, Pavel Didenko*, Yana Radionovskaya, Sofia Cherviak, and Marianna \\ Ermikhina
}

All-Russian National Research Institute of Viniculture and Winemaking "Magarach" of RAS, 298600 Yalta, Russia

\begin{abstract}
The article presents the results of studies, carried out in 20182020 in soil and climatic conditions of viticultural zone of the South Coast of Crimea on wine grape variety 'Cabernet-Sauvignon'. It was established that double application of national chelated micronutrient fertilizers Tiaton and Chelaton Extra for foliar dressing of grapes contributed to an increase in the average bunch weight by $9.3-15.3 \mathrm{~g}(10.3-16.9 \%)$, shoot productivity by $10.4-17.1 \%$ and cropping power by $0.6-1 \mathrm{t} / \mathrm{ha}$ (10-16.7\%) in comparison with the control. It was experimentally determined that test treatments with Chelaton Extra preparation led to a significant increase in the average length of annual shoots by $13.3 \mathrm{~cm}(9.3 \%)$ and a gain in the green matter of bushes by $265.9 \mathrm{~cm}^{3}(12 \%)$. Using of the studied micronutrient fertilizers against the background of increased grape productivity positively influenced the process of sugar accumulation and ensured the value component at the control level. The studies have proven that double treatment with Chelaton Extra fertilizer contributed to an increase in the mass concentration of phenolic substances in wine by $10.7 \%$.
\end{abstract}

\section{Introduction}

The application of foliar top dressing during the active growing season of plants is an important agricultural technique in the growing crops technologies, including grapes. Mineral fertilization contributes to the activation of a number of metabolic processes, especially under unfavorable (stressful) growing conditions [1, 2]. Most often, the limiting factor for the growth and development of grapes is the micronutrients deficiency. The application of microfertilizers has a positive effect on the biomass, winter hardiness, and drought resistance of plants, they increase the productivity of the grapevine, and improve the quality of products [3-6].

Along with high and stable grape yields, the task is to obtain high-quality raw materials for the production of competitive wines. It is commonly known that the quality of grapes is determined primarily by the acidity and sugar content of the juice of the berries. For the

\footnotetext{
*Corresponding author: pavel-liana@mail.ru
} 
production of table red wine it is necessary that the concentration of sugars in grapes is at least $170 \mathrm{~g} / \mathrm{l}$. Having other optimal conditions being equal, to achieve the necessary conditions of the grapes, it is important to provide the grape plants with sufficient nutrition elements such as phosphorus, potassium, magnesium, boron, etc. [7].

Microfertilizers in chelated form are of particular interest today, since the degree of their assimilation by plants can reach $90 \%$ (for example, for inorganic salts - 20-30\%) due to the fact that the inorganic substances that are in organic molecules easily penetrate through the wax coating of the leaf into the plant and saturate it with nutrients [8].

Since nowadays the increasing the yield, quality of fruit and berry products and grapes is a relevant aspect of the "Doctrine of Food Security of the Russian Federation", according to which the level of food self-sufficiency should be $60-70 \%$ [9], the purpose of our work was to assess the impact of national chelated micronutrient fertilizers on the productivity of grape plantations and the quality of table red wine made from Cabernet Sauvignon.

\section{Study objects and methods}

Field studies were carried out on industrial plantings of a valuable widespread technical grape variety Cabernet-Sauvignon during 2018-2020 in the soil and climatic conditions of the Southern Coastal viticultural zone of Crimea (branch "Livadia", JSC "PJSC "Massandra").

The objects of our research were the grapes of the technical variety Cabernet Sauvignon, as well as red table wines prepared from these samples.

The type of research is the field production experience. The area of the variant is 1 ha. Each variant has 45 accounting bushes in 3 replications. The placement of experimental variants is by means of elongated plots [10]. Method of application is tractor spraying (OVN400). The consumption rate of the working fluid is $8001 /$ ha.

The research scheme included two experimental feeding systems (double treatment with the studied microfertilizers) and a control one (farm feeding system, Table 1).

Table 1. Research scheme

\begin{tabular}{|c|c|c|c|}
\hline Variant & $\begin{array}{c}\text { Rate of } \\
\text { application }\end{array}$ & $\begin{array}{c}\text { Multiplicity } \\
\text { of treatments }\end{array}$ & $\begin{array}{c}\text { Treatment phases } \\
\text { (VVSN) }\end{array}$ \\
\hline $\begin{array}{c}\text { Control: } \\
\text { - Double Win P }\end{array}$ & $2.0 \mathrm{~kg} / \mathrm{ha}$ & 1 & \\
- Gumicfull Pro & $0.1 \mathrm{~kg} / \mathrm{ha}$ & 1 & \multirow{2}{*}{ 1) «end of flowering»; } \\
2umerries pea-size». \\
\cline { 1 - 2 } Experiment $2:$ Chelaton Extra & $1.0 \mathrm{~kg} / \mathrm{ha}$ & 2 & \\
\hline
\end{tabular}
8.0 .

Tiaton - liquid microfertilizer, containing sulfur in chelate form $(\mathrm{S})-4.24 \%, \mathrm{pH}=6.0$ -

Chelaton Extra - chelate microfertilizer, containing the complex of micronutrient elements: ferrum (III), zink (II), copper (II), cobalt (II), manganese (II), molybdenum (VI) in chelate form - for all by $0.6 \%$ and for boron $-0.2 \%$.

The technological scheme of red table wines preparation included the following process operations: destemming with crushing grapes, sulfiting of the pomace $(100 \mathrm{mg} / \mathrm{l}$ of total sulfur dioxide), maceration for 18 hours, fermentation (at a temperature of $22-24^{\circ} \mathrm{C}$, using the ' $47-\mathrm{K}$ ' yeast race (I -527, killer phenotype, from the Magarach collection of microorganisms of winemaking) up to $1 / 3$ of residual sugars, pressing of the pomace, afterfermentation, sulfiting ( $150 \mathrm{mg} / \mathrm{l}$ of total sulfur dioxide).

In the process of research we assessed the parameters of industrial ripeness of grapes: $\mathrm{pH}$, content of sugars, titratable acids and organic acids [11]. Tasting assessment (TA) of wines was carried out using 100-point scale. The following parameters were determined for wines: $\mathrm{pH}$, volume fraction of ethyl alcohol, mass concentration of the reduced extract, titratable 
acids and phenolic substances. The organic acid profile and glycerol content were determined by using a high performance liquid chromatography method (HPLC) on the Shimadzu LC20 Prominance chromatograph (Japan).

The obtained experimental entries were subjected to mathematical processing by generally accepted methods of descriptive statistics using the Statistica 6.0 and Ms Excel software packages. The confidence level of statistical analysis was 0.95 (95\%).

\section{Results and Discussion}

During the vegetation seasons of 2018-2019 the weather conditions were favorable for the grape plants' growth and development in the South Coast of Crimea. The passing of all phenological phases of grape vegetation was at the level of average long-term indicators.

Only the summer of 2020 was an exception, because it was hot and dry. A positive deviation of the average daily air temperatures from the long-term average data was observed in July and September by $0.7{ }^{\circ} \mathrm{C}$ and $1.9^{\circ} \mathrm{C}$, respectively. During the growing season of grapes, a low amount of precipitation was recorded $-130.8 \mathrm{~mm}$, which is $35.7 \%$ lower than the long-term average $(203.3 \mathrm{~mm})$.

The experiment was carried out on grape plants of the same potential productivity. The load of bushes with inflorescences on average over the years of research was 35.8-36.3 $\mathrm{pcs} / \mathrm{bush}$, therefore, a possible increase in the yield of grapes could depend only on the average weight of a bunch. During the research study the effect of chelated fertilizers on the number of clusters (inflorescences) was not established, while the coefficient of fertility (K1) and the coefficient of fruiting (K2) were 1.2 and 1.4, respectively.

Taking into account the quantitative indicators of the grape harvest showed that in all the studied indicators the experimental variants were superior to the control. The use of experimental nutrition systems on the technical variety of grape Cabernet-Sauvignon contributed to an increase in the average mass of the bunch by 9.3-15.3 g, an increase of the yield by $0.3-0.5 \mathrm{~kg} / \mathrm{bush}$ and the cropping capacity by $0.6-1.0 \mathrm{t} / \mathrm{ha}$ (Table 2 ). The largest increase in yield was noted in the experimental version with the use of Chelaton Extra preparation $-16.7 \%$. It was found that in terms of shoot productivity, the experimental variants exceeded the control one by 10.4-17.1\% (Table 2).

Table 2. The effect of the studied chelated microfertilizers on production performance of grape plants

\begin{tabular}{|c|c|c|c|c|c|}
\hline Variant & $\begin{array}{c}\text { Average } \\
\text { bunch } \\
\text { weight, } \mathrm{g}\end{array}$ & $\begin{array}{c}\text { Number of } \\
\text { bunches, } \\
\text { pcs/bush }\end{array}$ & $\begin{array}{c}\text { Shoot } \\
\text { productivity, } \\
\mathrm{g}\end{array}$ & $\begin{array}{c}\text { Cropping } \\
\text { capacity, } \\
\mathrm{t} / \mathrm{ha}, \mathrm{kg} / \\
\text { bush }\end{array}$ & $\begin{array}{c}\text { Cropping } \\
\text { capacity, } \mathrm{t} / \mathrm{ha}\end{array}$ \\
\hline Control & 90.1 & 33.3 & 108.1 & 3.0 & 6.0 \\
\hline Tiaton & 99.4 & 33.2 & 119.3 & 3.3 & 6.6 \\
\hline Chelaton Extra $^{\mathrm{HCP}} 05$ & 105.4 & 33.2 & 126.5 & 3.5 & 7.0 \\
\hline
\end{tabular}

At the next stage of the research work, the phytometric indicators of the grape vine which characterize the growth processes, the features of their passage were determined, being the important criteria for the architecture of the grape bush. It was found that two-time foliar top dressing with microfertilizer Chelaton Extra contributed to an increase of the vegetative mass of the bush by $12 \%\left(265.9 \mathrm{~cm}^{3}\right)$ and of the average shoot length by $9.3 \%(13.3 \mathrm{~cm}$, Table $3)$. These indicators in the variant using Tiaton were at the same level with the control $143.5-143.7 \mathrm{~cm}$ and $2220.3-2298.2 \mathrm{~cm}^{3}$, respectively. In terms of the values of the indicators "average shoot diameter" and "maturation of annual shoots" of grapes, regardless of the variant of the experiment, no significant differences were found. At the same time, annual 
shoots of grapes ripened by $91.5-94.5 \%$ of the total length of the shoot (ripening is classified as good). Grape shoots were medium-sized in terms of growth strength.

Table 3. The effect of the studied chelated microfertilizers on the phytometric parameters of grapes.

\begin{tabular}{|c|c|c|c|c|}
\hline Variant & $\begin{array}{c}\text { Average shoot } \\
\text { length (L), cm }\end{array}$ & $\begin{array}{c}\text { Average shoot } \\
\text { diameter (D), cm }\end{array}$ & $\begin{array}{c}\text { Bush } \\
\text { growth (P), } \\
\mathrm{cm}^{3}\end{array}$ & Ripeness, \% \\
\hline Control & 143.5 & 0.71 & 2220.3 & 91.5 \\
\hline Tiaton & 143.7 & 0.72 & 2298.2 & 94.5 \\
\hline Chelaton Extra & 156.8 & 0.72 & 2486.2 & 93.9 \\
\hline HCP05 & 7.9 & 0.1 & 52.6 & - \\
\hline
\end{tabular}

The conducted studies of grapes showed that all samples met the requirements of the stage of technical maturity (Table 4). The use of experimental fertilizer systems against the background of increasing the productivity of grapes had a positive effect on the process of sugar accumulation and ensured the content of the component at the control level. The discrepancy between the values of the indicator does not depend on the harvest year and does not exceed $3 \%$. A distinctive feature of the experimental batches of grapes was a higher content of titrated acids compared to the control (by 6-11\%). The profile of the acid complex of grapes was characterized by the tartaric acid predominance, while the maximum content of the component was noted in the variant of the experiment with the use of Chelaton Extra. The use of the preparation Tiaton provided a higher concentration of malic acid compared to the control (by $22.6 \%$ ). The experimental systems of mineral nutrition of grapes did not have a significant effect on the quantitative content of other components of the acid complex of grapes.

Table 4. Physicochemical indicators of grape harvest against the background of the use of chelated fertilizers

\begin{tabular}{|l|c|c|c|}
\hline \multicolumn{1}{|c|}{ Parameter } & Control & Tiaton & $\begin{array}{c}\text { Chelaton } \\
\text { Extra }\end{array}$ \\
\hline Mass concentration of sugars, g/l & 23.4 & 22.7 & 23.3 \\
\hline Mass concentration of titratable acids, g/1 & 6.5 & 6.9 & 7.2 \\
\hline $\mathrm{pH}$ & 3.32 & 3.40 & 3.34 \\
\hline Mass concentration of organic acids, g/l: & 5.3 & 5.0 & 5.6 \\
\hline titratable acids & 3.1 & 3.8 & 3.2 \\
\hline tartaric acid & 0.1 & 0.2 & 0.3 \\
\hline malic acid & 0.1 & 0.2 & 0.2 \\
\hline citric acid &
\end{tabular}

The dynamics of alcohol fermentation for all samples was identical and it lasted for 8-10 days. The values of the physical and chemical parameters of red table wines obtained from the analyzed grape samples are presented in Table 5. The analysis of the results shows that the treatment of grapes with microfertilizers Chelaton Extra and Tiaton ensures the accumulation of the mass concentration of the given extract in the wine at the control level. The increase in the content of titrated acids in the experimental samples with the use of the studied drugs was $4.5 \%$ and $9.7 \%$, respectively, which is a positive point in terms of protecting the drink from the development of harmful bacterial microflora and inhibiting the action of oxidative enzymes. The indicator of a higher value is provided by an increased content of malic acid (by 15.8-21\%) and succinic acid (by 2.4-2.6 times) compared to the control. It was found that the food system with microfertilizer Chelaton Extra contributes to a statistically significant increase in the mass concentration of phenolic substances in wine by $10.7 \%$. The obtained results have an important practical aspect, since the components of the phenolic complex determine the formation of the organoleptic characteristics of the drink. 
Table 5. Values of physicochemical parameters of wines

\begin{tabular}{|l|c|c|c|}
\hline \multicolumn{1}{|c|}{ Parameter } & Control & Tiaton & $\begin{array}{c}\text { Chelaton } \\
\text { Extra }\end{array}$ \\
\hline volume ratio of ethyl alcohol, \% & 13.0 & 12.3 & 13.2 \\
\hline $\mathrm{pH}$ & 3.55 & 3.60 & 3.63 \\
\hline mass concentration: & 26.4 & 26.9 & 26.2 \\
\hline total dry extract, g/1 & 6.7 & 7.4 & 7.0 \\
\hline $\begin{array}{l}\text { titratable acids, expressed in tartaric acid, } \\
\text { g/l }\end{array}$ & 1485 & 1390 & 1644 \\
\hline phenolic compounds, mg/l & 9.7 & 10.4 & 9.3 \\
\hline glycerol, g/1 & \multicolumn{3}{|l}{} \\
\hline organic acids, g/l: & 4.2 & 4.4 & 4.2 \\
\hline tartaric acid & 1.9 & 2.3 & 2.2 \\
\hline malic acid & 0.5 & 0.4 & 0.6 \\
\hline lactic acid & 0.9 & 2.2 & 2.3 \\
\hline succinic acid & 0.1 & 0.1 & 0.1 \\
\hline citric acid & 0.2 & 0.2 & 0.1 \\
\hline acetic acid & 78 & 76 & 79 \\
\hline Tasting assessment, point & \multicolumn{3}{|l}{} \\
\hline
\end{tabular}

The organoleptic evaluation showed that regardless of the variant of the experiment, the wines were characterized by rich red color, a prominent varietal aroma with berry direction and a harmonious flavour. The tasting score was in the range of 76-79 points. The samples with the experimental system for processing micronutrient fertilizers Chelaton Extra received the maximum assessment due to their fresher and fuller taste, provided by a higher level of titratable acids and phenolic substances.

\section{Conclusion}

Thus, based on the results of three-year studies on the effect of the use of chelated micronutrients in foliar treatments of Cabernet-Sauvignon grape plants in the conditions of the southern coast of Crimea, the following conclusions can be made:

- a significant increase in the cropping capacity of technical grapes in the experimental variants was obtained - 0.6-1.0 t / ha (10-16.7\%), due to a significant increase in the average mass of a bunch by 9.3-15.3 g, while the productivity of shoots exceeded the control by 10.4$17.1 \%$;

- a noticeable rise in the average length of shoots and the growth of grape bushes was determined in the experimental plot treated with the Chelaton Extra fertilizer by $13.3 \mathrm{~cm}$ $(9.3 \%)$ and $265.9 \mathrm{~cm}^{3}(12 \%)$, respectively;

- it was found that the use of experimental systems of mineral nutrition provides a conditioned harvest of grapes with a higher content of titratable acids in comparison with the control (by 6-11\%). The increase of this indicator in wine is $4.5-9.7 \%$ and it provides a fresher and more harmonious flavour;

- it was emphasized that double feeding with micronutrient fertilizer Chelaton Extra aids the growth of the mass concentration of phenolic substances in wine by $10.7 \%$. The trial wines were characterized by rich red color, prominent varietal aroma with berry direction and fresh full flavour.

In general, after three years of application of national micronutrient fertilizers in chelated form Tiaton and Chelaton Extra on the plot of the valuable Cabernet Sauvignon variety, the yield and the volume of growth of grape plants has increased, and it did not adversely affect the physicochemical indicators of grapes and the quality characteristics of the wine. 


\section{Acknowledgements}

We express our deep gratitude to the staff of the SIC "Kurchatov Institute" - IREA: N.V. Tsirulnikova, Doctor of Chemical Sciences, for the invention and development of the studied chelated microfertilizers and to E.A. Nikulina, Candidate of Technical Sciences, member of research staff, for participation in our work and for the provision of these preparations for our research.

\section{References}

1. S.V. Levchenko, A.A. Batukaev, I.A. Vasylyk et al., Advances in Engineering Research, 151, 900 (2018)

2. M. Arrobas, I.Q. Ferreira, S. Freitas, J. Verdial, M.A. Rodrigues, Sci Hortic-Amsterdam, 172, 191 (2014)

3. M.M. Terra, M.O.C. Brazil-Sobrinho, E.J.P. Pires, V. Nagai, Acta Horticultural, 526, 235 (2000)

4. I. Grechi, Ph. Vivin, G. Hibert, S. Milin, T. Robert, J.-P. Gaudillere, Environmental and Experimental Botany, 59, 139 (2007)

5. P. Martin, R. Regaldo, M.R. Gonzales, J.I. Gallegos, Acta Horticultural, 652, 342 (2004)

6. S. Frost, L. Lerno, J. Zweigenbaum, H. Heymann, S. Ebeler, Molecules, 23 (10), 2687 (2018)

7. E.N. Yakimenko, N.M. Ageeva, V.S. Petrov, Y.M. Mikheeva, Magarach. Viticulture and winemaking, 22 (1), 39 (2020)

8. N. Aleinikova, N. Tsirulnikova, P. Didenko, E. Nikulina, Magarach. Viticulture and winemaking, 22 (3), 216 (2020)

9. E.A. Yegorov, G.A. Shadrina, G.A. Kochian, Fruit growing and viticulture of the South of Russia, 61 (1), 1 (2020)

10. V.G. Sychev, O.A. Shapoval, I.P. Mozharova et al. Guidelines for the registration tests of agrochemicals in agriculture: production and practical edition (2018)

11. Office international de la vigne et du vin, Compendium of international methods of wine and must analysis (2017) 